\title{
Proliferation of synovial lining cells and fibroblasts
}

\author{
W. MOHR, G. BENEKE, AND W. MOHING \\ From Department of Pathology II, University of Ulm, Germany
}

\begin{abstract}
Mohr, W., Beneke, G., and Mohing, W. (1975). Annals of the Rheumatic Diseases, 34, 219 224. Proliferation of synovial lining cells and fibroblasts. After in vitro incubation with ${ }^{3} \mathrm{H}$ thymidine, the proliferation of synovial lining cells and fibroblasts was investigated in surgically-removed articular tissue. Under normal conditions, in nonrheumatoid arthritis and in osteoarthrosis, low proliferation rates for both cell types were observed. In rheumatoid arthritis, the rate of proliferation of both cell types was usually increased. An increased proliferation of the synovial lining cells was especially observed in cases with a hyperplastic lining cell layer and in cases with a minimal lymphocytic and plasma cellular infiltration in the synovial membrane.
\end{abstract}

Hyperplasia of the synovial lining cell layer is an early (Kulka, Bocking, Ropes, and Bauer, 1955) and characteristic (Barland, Novikoff, and Hamerman, 1964; Hirohata and Kobayashi, 1964; Wyllie, Haust, and More, 1966; Fassbender, 1971; Klein, Rosenbauer, Rupprecht, Krämer, and Huth, 1972) morphological feature of rheumatoid arthritis. It may be assumed that the accumulation of cells leading to a broadening of the lining cell layer is due to an increased cell proliferation. However, mitoses of synovial lining cells are rarely encountered either under physiological conditions or in rheumatoid arthritis. Therefore, no information on the proliferation of the cells in the synovial membrane is available.

To understand the pathological process in rheumatoid arthritis it may be worthwhile to acquire knowledge of the proliferation dynamics of the cells of the synovial membrane. Such information may be obtained by using the in vitro technique with ${ }^{3} \mathrm{H}$ thymidine labelling, as was done by Takasugi and Hollingsworth (1968) on synovial fluid cells.

\section{Materials and methods}

Investigations were carried out on surgically removed synovial tissue. Immediately after removal small pieces were incubated in buffer-solution (Krebs-HenseleitRinger solution) with ${ }^{3} \mathrm{H}$-thymidine $(2 \mu \mathrm{Ci} / \mathrm{ml}$; specific activity: $2 \mathrm{Ci} / \mathrm{mmol}$ ) for $1 \mathrm{~h}$ at $37^{\circ} \mathrm{C}$. Thereafter, the tissue was fixed in buffered $4 \%$ formaldehyde, and $5 \mu \mathrm{m}$ thick paraffin sections were made. For autoradiographic purposes the sections were coated with Ilford $L 4$ nuclear research emulsion and were kept in tight boxes for 2 weeks at $4^{\circ} \mathrm{C}$. After developing they were stained with haematoxylin-eosin. The number of labelled nuclei in 1000 cells (synovial lining cells and fibroblasts in the upper synovial membrane, respectively) was assessed for each cell type examined. A total of 52 joints from 38 patients was investigated (Tables I and II).

In haematoxylin-eosin stained sections, the degree of the lymphoplasmacellular infiltration and the hyperplasia

Table I Origin of articular tissue investigated

\begin{tabular}{|c|c|}
\hline Joints investigated & Number of joints \\
\hline Knee & 38 \\
\hline Hip & 2 \\
\hline Shoulder & 2 \\
\hline Elbow & 3 \\
\hline Hand/finger & 7 \\
\hline Total no. of joints & 52 \\
\hline Total no. of patients & 38 \\
\hline
\end{tabular}

Table II Diagnosis and number of cases investigated

No. of joints with rheumatoid arthritis

45

No. of joints with osteoarthrosis

No. of joints with nonrheumatoid arthritis

3

No. of cases with normal synovial membrane 
of the synovial lining cell layer were determined. A synovial lining cell layer consisting of more than three synoviocytes was said to be 'broadened'. Representative cases are shown in Figs 1 and 2. In Fig. 1 there is no hyperplasia (broadening) of the synovial lining cell layer, whereas the synovial membrane is infiltrated with lymphocytes and plasma cells (high density). Fig. 2 shows hyperplasia of the synovial lining cell layer and only minimal lymphocytic and plasma cellular infiltration (low density) in the synovial membrane.

\section{Results}

LOCALIZATION OF ${ }^{3}$ H-THYMIDINE LABELLED CELLS IN THE SYNOVIAL MEMBRANE

In the synovial lining cell layer cells with labelled nuclei were observed in superficial as well as in deeper areas (Fig. 3). Labelling of fibroblasts was also noticed in all parts of the upper synovial membrane (Fig. 4). In some cases labelling of endothelial cells was found (Fig. 4).

LABELLING INDICES OF SYNOVIAL LINING CELLS AND FIBROBLASTS

In one of our cases a normal synovial membrane was examined. As seen in Fig. 5, the labelling rates for both cell types examined are extremely low. In the synovial lining cell layer $0.05 \%$ labelled cells, and in $\vec{\circ}$ the upper synovial membrane $0.1 \%$ labelled fibroblasts, were encountered. Slightly increased numbers $\vec{\omega}$ of labelled cells were observed in osteoarthrosis and

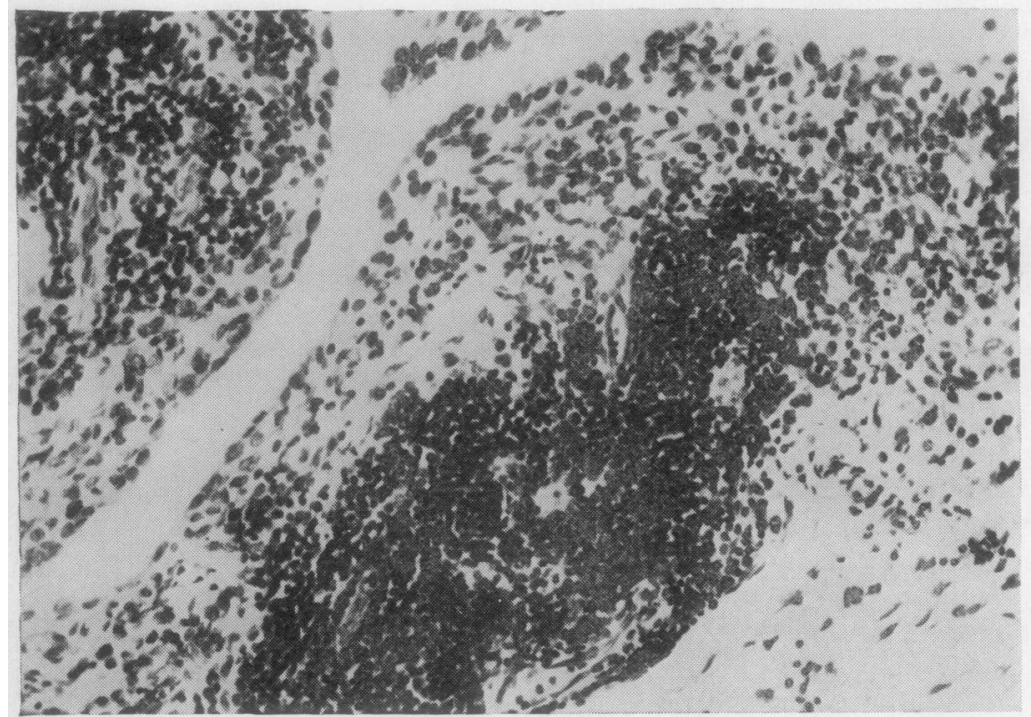

FIG. 1 Synovial membrane with $\vec{c}$ dense lymphocytic and plasma cellular infiltration. The lining cell layer is not broadened. Haema- $\vec{v}$ toxylin-eosin $\times 176$

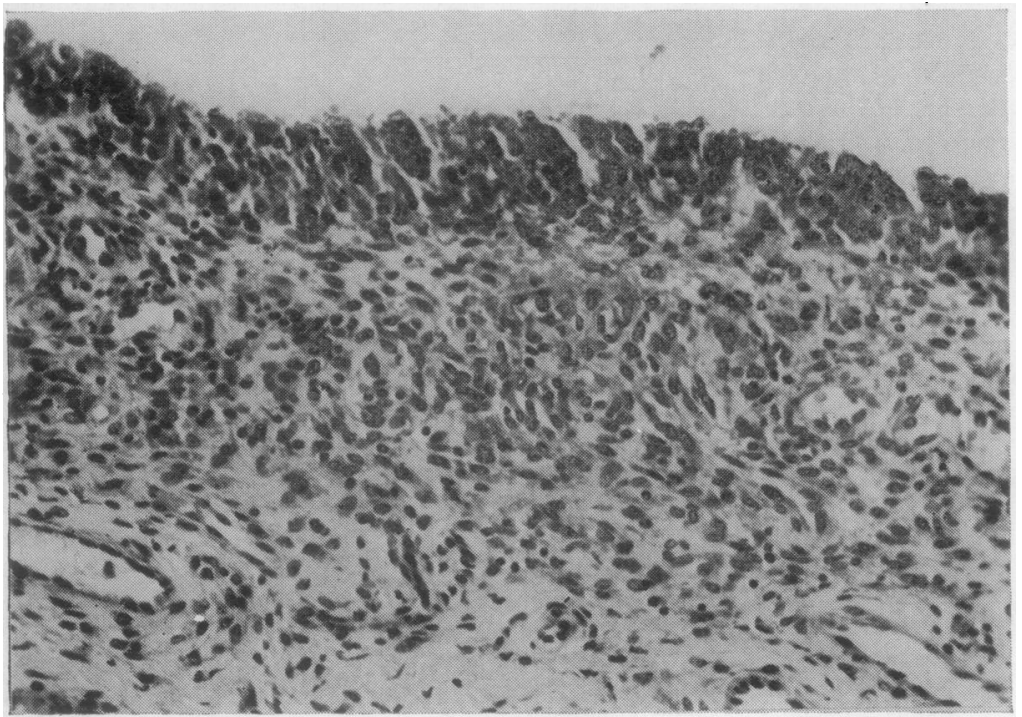

FIG. 2 Synovial membrane with a low degree of lymphocytic and plasma cellular infiltration. The synovial lining cell layer is hyper- N plastic. Haematoxylin-eosin $\times 176 \mathrm{~N}$ 


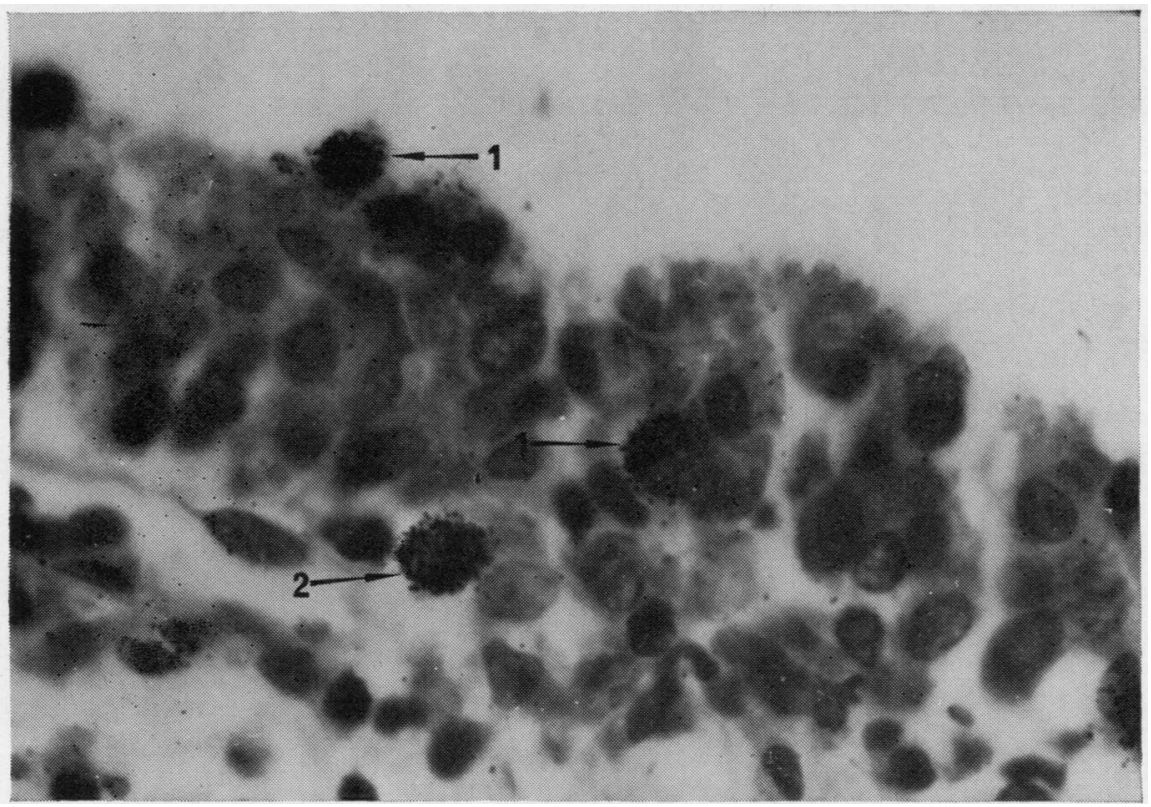

FIG. $3{ }^{3}$ H-thymidine labelled synovial lining cells (1), and fibroblasts in the upper synovial membrane (2). Haematoxylin$\operatorname{eosin} \times 780$

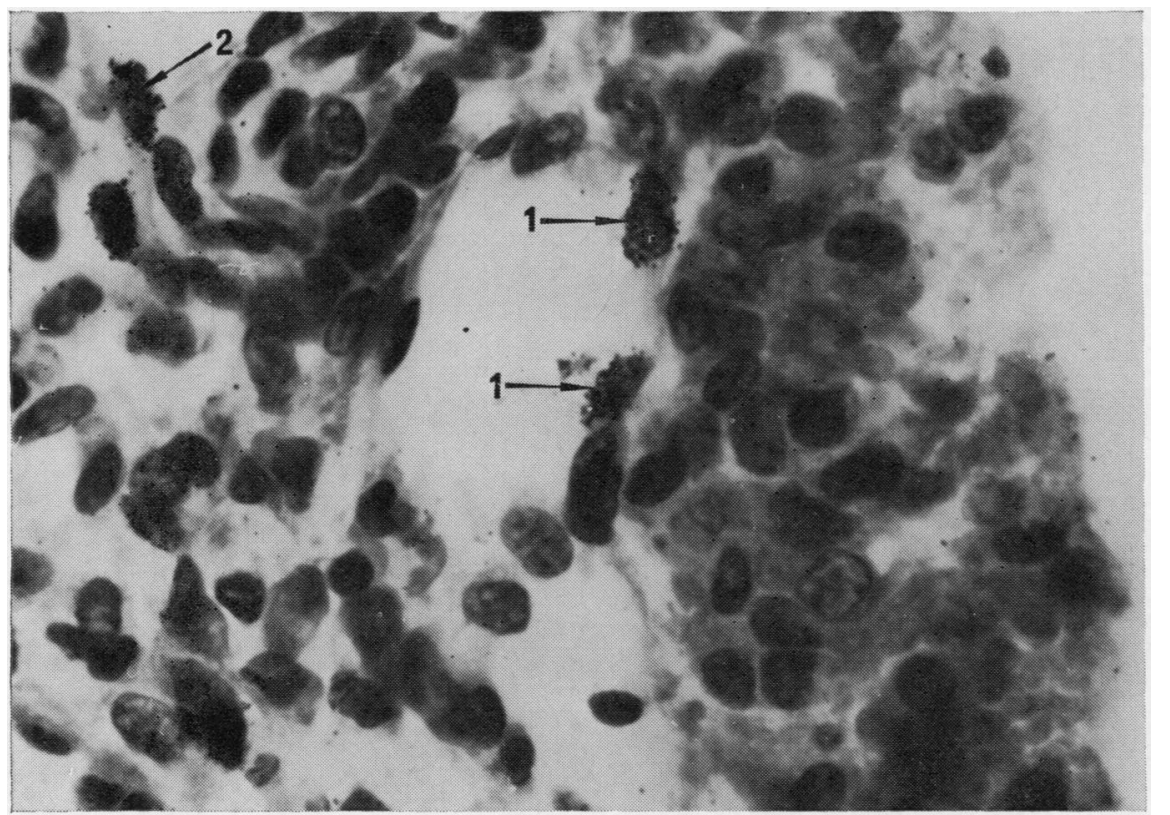

FIG. $4{ }^{3}$ H-thymidine labelled endothelial cells (1), and fibroblasts in the upper synovial membrane (2). Haematoxylin$\operatorname{eosin} \times 780$

nonrheumatoid arthritis (Fig. 5). The greatest number of labelled cells was seen in cases of rheumatoid arthritis. In these cases labelling rates up to $4.2 \%$ for synovial lining cells and $3.8 \%$ for fibroblasts were detected. However, there were some cases with a very low number of labelled cells. Furthermore, in some cases of rheumatoid arthritis, labelled cells only appeared in the synovial lining cell layer; in others, labelled cells were only seen in the superficial synovial membrane. 


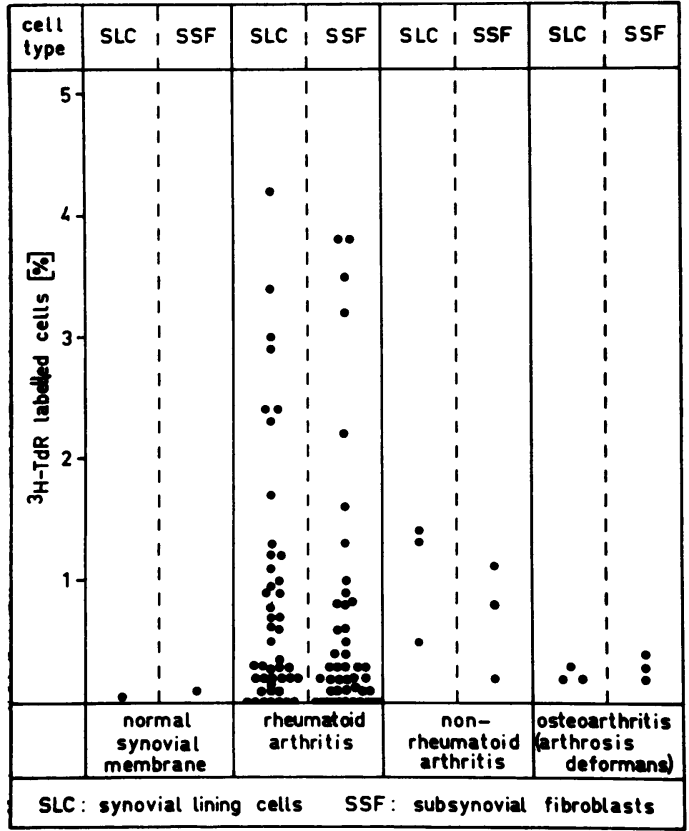

FIG. 5 Labelling indices of synovial lining cells and fibroblasts under physiological conditions in rheumatoid arthritis, in nonrheumatoid arthritis, and in osteoarthrosis

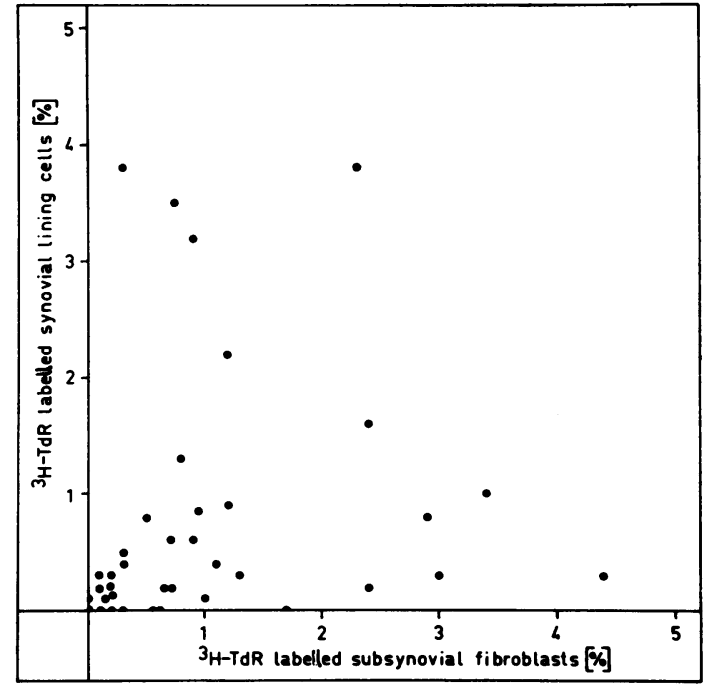

FIG. 6 Correlation of the labelling rates for synovial lining cells and fibroblasts in rheumatoid arthritis

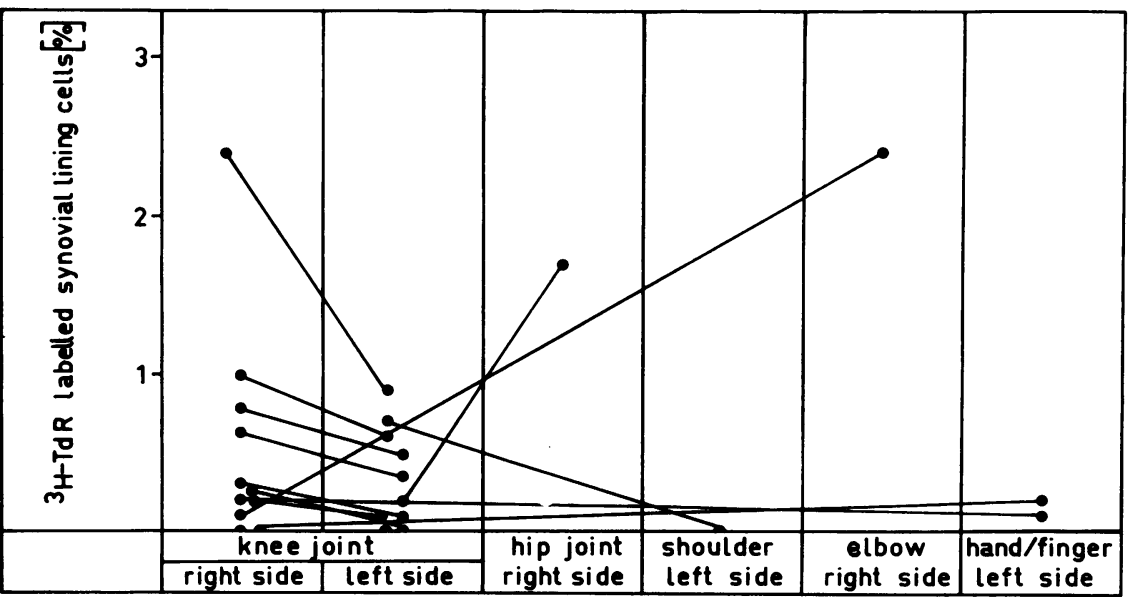

FIG. 7 Labelling rates of synovial lining cells in different joints of the same patient. Points connected by a line belong to the same patient

In Fig. 6 the labelling indices of synovial lining cells are correlated with those of the subsynovial fibroblasts. It is evident that there is not in all cases a direct correlation between the labelling rates of both cell types. This is especially true for cases with a high number of labelled cells. In contrast, cases with low labelling rates often showed a stronger correlation between both cell types.
LABELliNG OF SYNOVIAL LINING CELLS IN DIFFERENT JOINTS OF THE SAME PATIENT IN $\stackrel{\leftrightarrow}{?}$ RHEUMATOID ARTHRITIS

From twelve patients it was possible to investigate articular tissue from two joints. The results are summarized in Fig. 7. It can be seen that in 9 of these cases the labelling indices were nearly identical in the two different joints. However, in 3 cases obvious dif- 


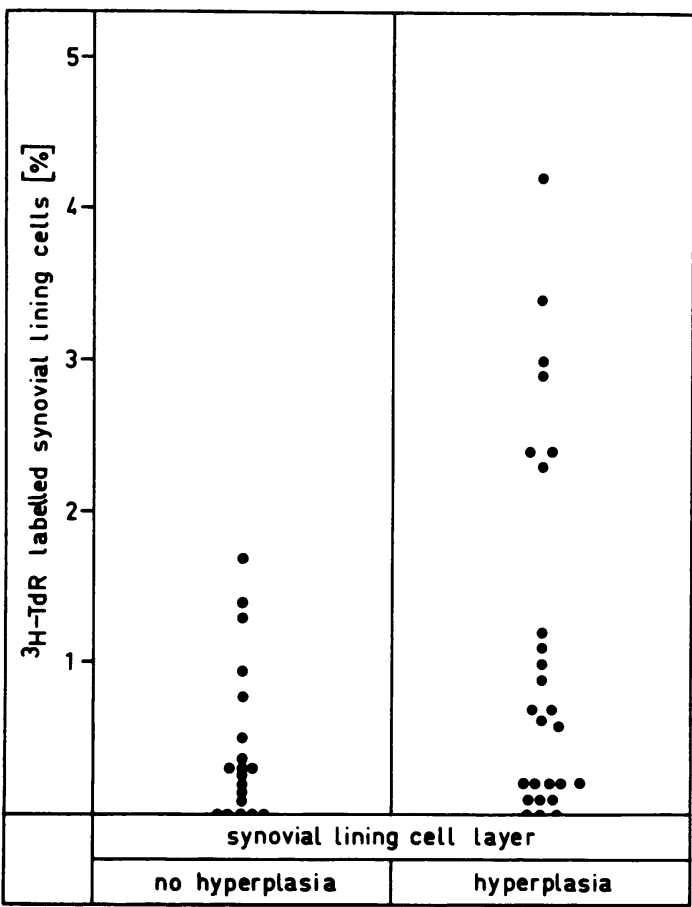

FIG. 8 Influence of the structure of the synovial lining cell layer on the labelling rates of lining cells in rheumatoid arthritis

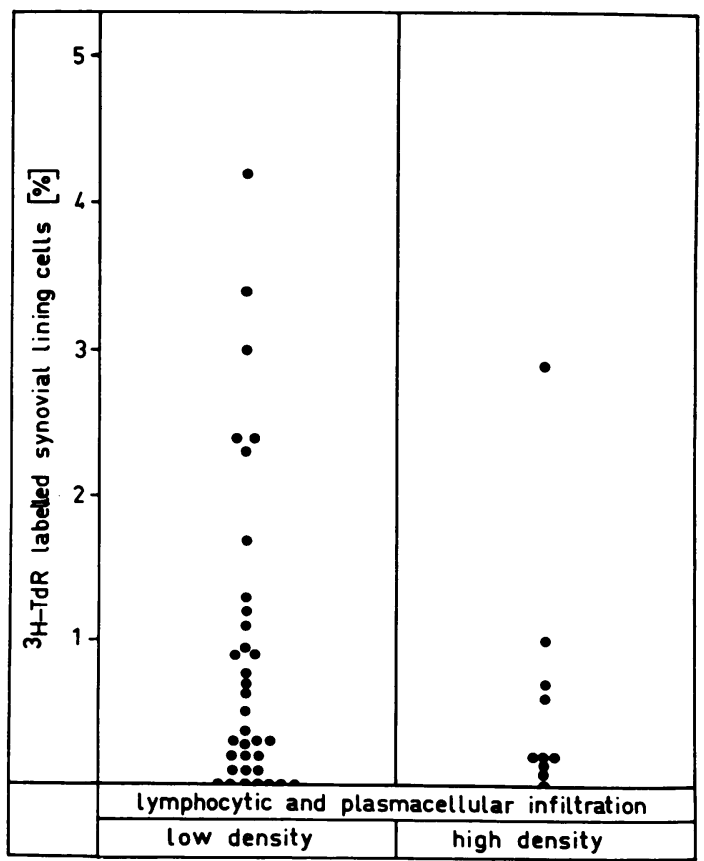

FIG. 9 Influence of the lymphocytic and plasma cellular infiltration in the synovial membrane on the labelling rates of lining cells in rheumatoid arthritis ferences were noticed between the two joints. This result may indicate differences in the intensity of the inflammatory process in different joints of the body.

INFLUENCE OF THE STRUCTURE OF THE SYNOVIAL LINING CELL LAYER ON THE LABELLING RATE OF LINING CELLS IN RHEUMATOID ARTHRITIS

The cases of rheumatoid arthritis under examination were divided into those with hyperplasia of the lining cell layer and those with a normal lining cell layer. As shown in Fig. 8 a hyperplastic lining cell layer is usually correlated with a high rate of labelled lining cells. On the other hand, it can be seen that a low incidence of labelled lining cells is present when this cell layer is not broadened.

INFLUENCE OF CELLULAR INFILTRATION IN THE SYNOVIAL MEMBRANE ON THE LABELLING RATE OF LINING CELLS IN RHEUMATOID ARTHRITIS

From Fig. 9 it is evident that in most cases the highest labelling rates of lining cells were seen when the cellular infiltration with lymphocytes and plasma cells was of low density or nearly absent. However, in most cases with a dense cellular infiltration, labelling rates usually were low.

\section{Discussion}

The present investigations showed that the labelling rates of synovial lining cells and fibroblasts are low under normal conditions, in osteoarthrosis, and even in cases of nonrheumatoid arthritis. However, in rheumatoid arthritis, high labelling rates for both cell types were observed.

Despite the fact that mitoses of synovial lining cells and fibroblasts are rarely encountered in rheumatoid arthritis, it must be concluded that the high labelling rates indicate an increased cell proliferation. This conclusion is supported by cytophotometric investigations in which no higher degree of polyploidization of synovial lining cells could be observed (Mohr, Beneke, and Mohing, 1973). However, we cannot decide if the higher cell proliferation results only in cell augmentation or if there is also cell death which leads to the formation of new cells. The appearance of labelled synovial lining cells in all parts of the synovial cell layer indicates that a basic stem cell does not exist, as in true epithelial tissues, but that all cells are able to proliferate.

By correlating the rates of proliferation of synovial lining cells with the morphological appearance of the synovial membrane, two interesting results were obtained.

1 If the proliferation of the synovial cell layer is regarded with respect to the structure of the lining cell 
layer, it can be seen that the proliferation is increased when this cell layer is hyperplastic. From this result it can be deduced that broadening of the lining cell layer indicates progression of the proliferative inflammatory process. This fact was assumed by pathologists who are familiar with the histological changes in rheumatoid arthritis (Muirden and Mills, 1971) and this fact is now proved by these cell kinetic studies.

2 The density of the lymphocytic and plasma cellular infiltration is correlated with the proliferation rate of the lining cells. In most cases with a dense cellular infiltration, the proliferation of these cells was usually lower than in cases which had only a minimal infiltration. However, from the present investigations no definite conclusion can be drawn, for in some cases an inverse relationship was seen. Nevertheless, it may be assumed that the lymphocytic and plasma cellular infiltration has an inhibitory effect on the progression of the proliferative inflammatory process as was stated by Muirden and Mills (1971).

The investigations were supported by a grant from the Deutsche Forschungsgemeinschaft.

\section{References}

Barland, P., Novikoff, A. B., and Hamerman, D. (1964) Amer. J. Path., 44, 853 (Fine structure and cytochemistry of the rheumatoid synovial membrane, with special reference to lysosomes)

FassBender, H. G. (1971) In 'Rheumatoid Arthritis', eds. W. Müller, H.-G. Harwerth, and K. Fehr. Academic Press, New York

Hirohata, K., AND KobaYASHi, I. (1964) Kobe J. med. Sci., 10, 195 (Fine structure of the synovial tissues in rheumatoid arthritis)

Klein, W., Rosenbauer, K. A., Rupprecht, L., Krämer, J., ANd Huth, F. (1972) Virchows Arch. path. Anat., 357, 359 (Beitrag zur Kenntnis der juvenilen monoartikulären rheumatoiden arthritis)

Kulka, J. P., Bocking, D., Ropes, M. W., ANd Bauer, W. (1955) Arch. Path., 59, 129 (Early joint lesions of rheumatoid arthritis)

Mohr, W., Beneke, G., AND Mohing, W. Z. (1973) Rheumaforsch., 32, 428 (Zytophotometrische Untersuchungen zur Proliferation der Synovialzellen (lining cells) bei rheumatoider Arthritis)

MuiRDEN, K. D., AND Mills, K. W. (1971) Brit. med. J., 4, 219 (Do lymphocytes protect the rheumatoid joint?)

TAKASUgi, K., AND Hollingsworth, J. W. (1968) Arthr. and Rheum., 11, 44 (Incorporation of tritiated thymidine into mononuclear cells of human synovial effusions

Wyllie, J. C., Haust, M. D., AND MoRe, R. H. (1966) Lab. Invest., 15, 519 (The fine structure of synovial lining cells in rheumatoid arthritis) 